\title{
Critical Literacy Development In Action!
}

\section{Janis Massa ${ }^{1}$ and Limor Pinhasi-Vittorio ${ }^{2}$}

In this article, we explore the determinants of critical literacy development and of social and academic transformation. Knowledge of such determinants is prerequisite to the act of creating effective classroom policy that builds on the academic, social and language experience of the students rather than on the background experience of teachers, administrators and policy makers who create and enforce educational policy. Pedagogical implications are drawn from a close examination of various novels and texts which are suitable for $\mathrm{k}$ to college-level classrooms and can encourage a broader look at society. These implications focus on how literacy, and in particular critical literacy, can be used to question the texts and raise social awareness of societal values, thereby promoting social justice. [Article copies available for a fee from The Transformative Studies Institute. E-mail address: journal@transformativestudies.org Website: http://www.transformativestudies.org (C2009 by The Transformative Studies Institute. All rights reserved.]

KEYWORDS: Urban Education, Critical Literacy, Critical Pedagogy, Transformative Education.

\footnotetext{
${ }^{1}$ Janis Massa, Ph.D., is Assistant Professor, Department of English, Lehman College, City University of New York. Janis Massa is a social activist who teaches graduate and incoming freshmen in the Department of English at Lehman College. Her research interests focus on urban education and second language acquisition. Address correspondence to: Janis Massa, Lehman College, Department of English, Carman Hall 394, 250 Bedford Park Blvd West, Bronx, NY 10468; e-mail: Janis.massa@lehman.cuny.edu.

${ }^{2}$ Limor Pinhasi-Vittorio, Ph.D., is Assistant Professor of Literacy and the coordinator of the graduate program in Lehman College. Address correspondence to: Dr. Limor Pinhasi-Vittorio, Lehman College, Department of Counseling, Leadership, Literacy and Special Education, Division of Education, Carman Hall B-20, 250 Bedford Park Blvd West, Bronx, NY 10468; e-mail: LIMOR.PINHASI-VITTORIO@lehman.cuny.edu. Acknowledgements: We wish to thank Labid Ereifej, Charles Gallo, L. Mike Massa, and Joanne Risbano-Sarver.
} 